\title{
Quality engineering tools in analysis of failure of longwall mining complex
}

\begin{abstract}
Downtimes caused by machine failures translate into a loss of effectiveness in the mining process. The main task of maintenance teams in hard coal mines is to ensure the uninterrupted work of the machines used. A measurable effect of these activities should be reducing machine maintenance and, as a consequence, reducing the costs of coal mining; i.e., a mine's operating costs. In the present article, two longwall mining machines have been analyzed: a cutter-loader and a plow. The analysis was based on one of the quality engineering tools - the Pareto-Lorenz diagram. This tool allows for grouping the causes of breakdowns and establishing which of them are the most important and should be removed first. The analysis has demonstrated the significance of machine selection and its adjustment to the existing geological-mining conditions. Improper selection results in increased energy consumption in the mining process, premature wear, or prolonged downtimes caused by breakdowns.
\end{abstract}

Key words: longwall mining machines, breakdowns, output, Pareto-Lorenz diagram

\section{INTRODUCTION}

In coal mining (both global and Polish), exploitation of coal seams is done with longwall systems using cutting machines that machine the face. Thus, one of the important areas of a mine's activity is the operation of the machinery and equipment necessary for its proper functioning. This activity should include, among others, supervision over the effective and rational use and maintenance of machines and devices in the process of their exploitation [1-4]. At present in Polish (as well as world) mining, two systems are applied: a shearer (Fig. 1) and a plow (Fig. 2). The mining process in both systems is identical; the difference lies in the cutting machine installed (shearer or plow). The other elements of the system remain unchanged.

The efficiency of a properly designed mechanization system and its reliability directly affect the economic result of the company. The technological development in mining as well as the increasing complexity, efficiency, and power of mining machinery and equipment puts ever greater demands on the cul- ture of their use. These devices must meet the conditions of energy efficiency, reliability, high durability, and work safety.

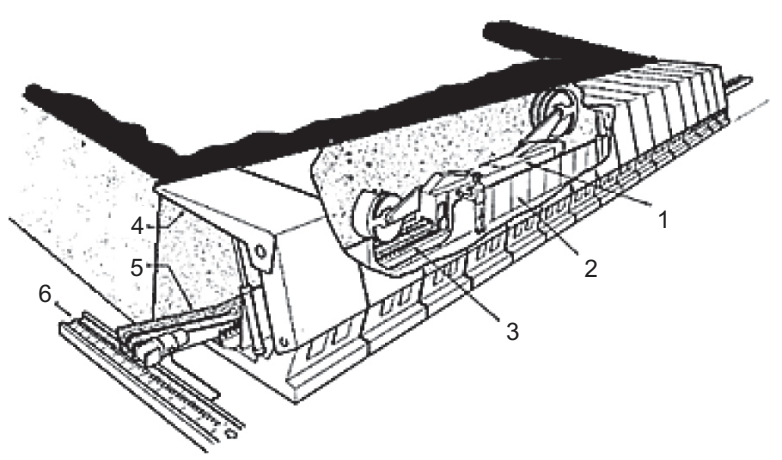

Fig. 1. Longwall shearer system: 1 - shearer,

2 - spill plate, 3 - ladder, 4 - powered roof support, 5 - armored face conveyor, 6 - beam stage loader [1]

Mining machines and equipment are complex technical objects that should be characterized by adequately high durability and reliability of operation over a relatively long period of exploitation. The formation of these features is influenced not only by the very process of their design, construction, and 
assembly but above all (during the broadly defined process of use) proper attention to their technical condition. The use of technical diagnostics, which allows us to correctly determine the technical condition of machines, guarantees reliability and the high durability of the equipment during operation. Therefore, the main task of mine maintenance services is to ensure the continuity of operation of the machines and equipment operated at a given moment. The consequence of these activities is a reduction of maintenance costs in the machines and equipment, which is associated with a reduction in production costs; that is, the operation of the mining plant. Disruptions in this process generate great losses.

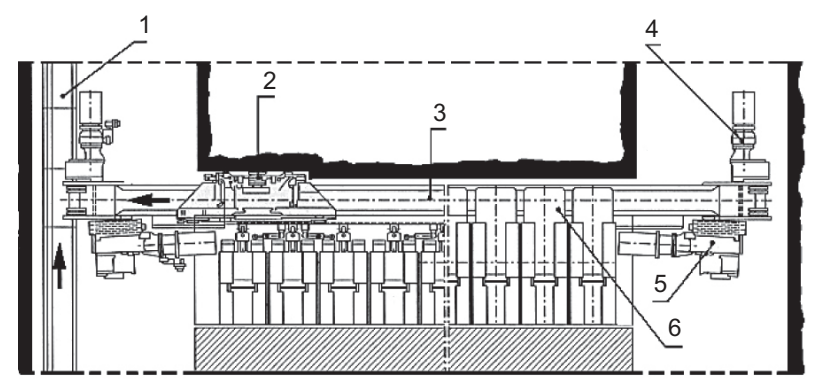

Fig. 2. Longwall plow system: 1 - beam stage loader,

2 - plow, 3 - armored face conveyor, 4 - conveyor

drive, 5 - plow drive, 6 - powered roof support [1]

In the present paper, one of the traditional quality management tools - the Pareto-Lorenz diagram was used to assess the failure rate of mining machines and equipment $[4,5]$. This chart allows us to present both the relative and absolute distribution of the types of errors, problems, and reasons for their formation [6].

In the process of extracting minerals, the main element is the mining process line, in which three consecutive stages can be distinguished $[1,4]$ :

- extraction process,

- horizontal transport,

- vertical transport.

By analyzing the mining process line, it can be seen that it is a serial system - failure of one of the links causes the "disabling" of the other elements on the line (Fig. 3).

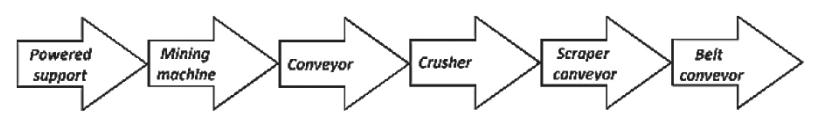

Fig. 3. Components of mining process line

\section{MINING PROCESS LINE MAINTENANCE}

The maintenance of mining machines and equipment is carried out by services connected to the mine as well as by external companies. In the case of external companies, they are most often the manufacturer of a given machine or device.

Every machine or device installed in a mine is subject to maintenance and repair activities that can be broken down into factors that allow them to be properly located in the repair structure (Fig. 4):

- repairs/maintenance of hydraulic (pneumatic) elements,

- repairs/maintenance of mechanical elements,

- repairs/maintenance of electrical elements.

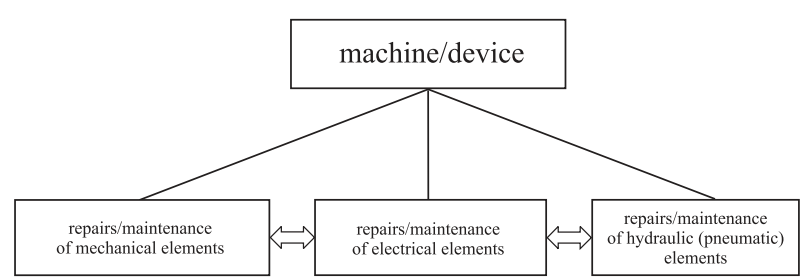

Fig. 4. Block diagram of repair structure

The model currently used for collecting data on the failures of mining machines/equipment in one of the PGG mines is shown in Figure 5.

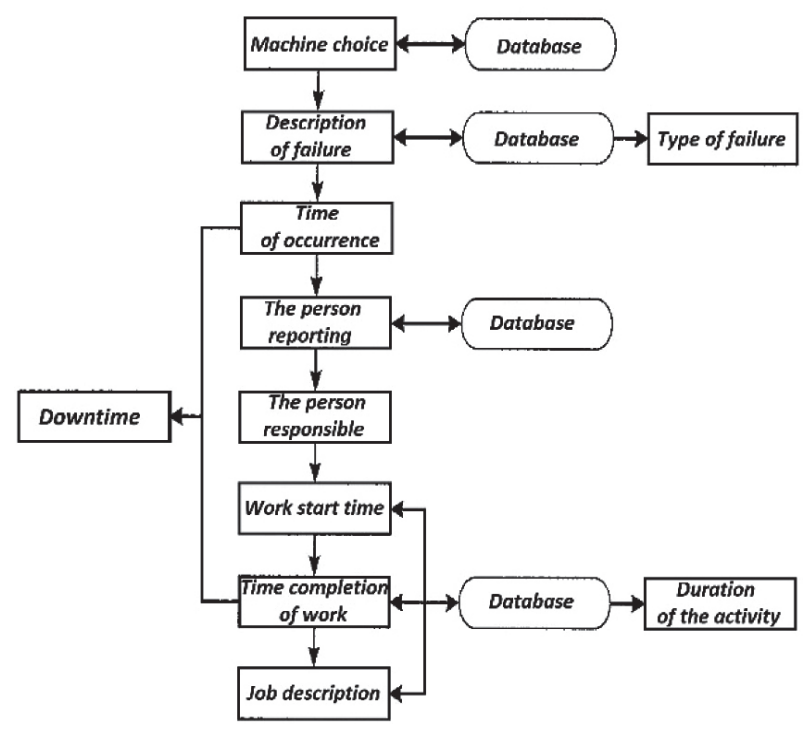

Fig. 5. Diagram of registration of machine/equipment failure at PGG mine

Based on observations, it can be stated that Polish hard coal mines have not developed a uniform management system for managing the maintenance of mining machines as of yet; neither during their opera- 
tion nor during repairs. The system should include the following [1]:

- observation, registration, and analysis of individual activities;

- scheduling activities;

- a method of gathering information about the machines and equipment;

- a way of establishing the scope of service work between the user and the manufacturer;

- shaping the right competences of employees performing maintenance activities;

- collection and processing of information pertaining to maintenance works.

Quality engineering can be used to monitor and control the machinery/equipment of a longwall mining complex. The use of quality engineering elements in the majority of manufacturing enterprises is aimed at detecting the occurrence of potential defects in the product or production cycle. The use of quality management tools allows for the monitoring of the production cycle, starting from the design phase through production and to the final stage; that is, delivering the finished product to the customer. Quality engineering tools for assessing the effects of failures will significantly reduce losses that are associated with unplanned downtime (breakdowns). Thus, it seems justified to use quality engineering tools in the production (mining) process that will allow for an effective reduction of losses resulting from failures. Therefore, it is suggested to include quality engineering elements in the determination of the causes of failures in the mining process (Fig. 6).

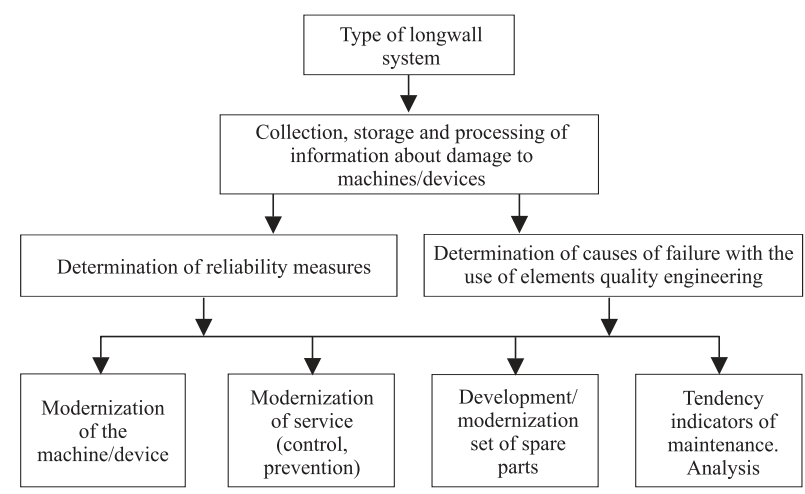

Fig. 6. Quality engineering in determining causes of failure

The practical application of selected elements of quality engineering in the production process (in this case - mining) reduces the losses associated with downtime resulting from machine/equipment breakdowns.

\section{QUALITY ENGNEERING AND MACHINE/EQUIPMENT FAILURE RATE}

Quality engineering is understood as the shaping, modeling, and implementation of quality systems according to specific standards and norms, quality management, quality system certification methods, accreditation and audit methods, process control, metrology, legal aspects of quality, and methods of total quality management (TQM).

First and foremost, the management staff requires information for effective quality management. The information must be reliable, current, and (above all) true. Quality management is aimed at improving products and/or services - creating and assuring their quality so as to satisfy the customer. It is a comprehensive activity, and various tools and methods help in its implementation.

Quality tools are used to collect and process information, supervise the quality management process, and detect errors, defects, and irregularities in the processes, products, and services. They allow one to visualize the data as well as monitor and diagnose the processes. Thanks to these, the effectiveness of the actions taken can be assessed; they are instruments that allow for the monitoring of activities (processes) throughout the product's life cycle.

Quality management tools are divided into traditional, new, and auxiliary. Traditional tools are called the magnificent seven. They are the most commonly used and fundamental ones. These tools can be used alone but are often used as components of quality management methods. One of the traditional quality management tools is the Pareto-Lorenz diagram [7-9].

The Pareto-Lorenz diagram (also called the ABC method, the law of non-uniformity of distribution, or the law of 20-80) is used to identify and assess the significance of the issues analyzed. It identifies the problems that, despite being the minority as related to the number of all problems (20\%), exert a dominant influence on the considered issue $(80 \%)$.

The procedure for conducting an analysis according to the $\mathrm{ABC}$ method consists of the following:

- identification of the types of issues considered (e.g., types of defects);

- determination of the time interval (day, change, year, etc.) for later comparison of the effects of the implemented changes;

- determining the frequency of occurrence of particular categories (e.g., causes, defects); 
- classification of categories in descending order by frequency of occurrence, calculation of percentages, and cumulative rates;

- determination of scales on the vertical (most often designated as absolute frequency and cumulative percentage) and horizontal axes (categories);

- plot bars corresponding to the frequency for individual categories (Pareto chart) and the curve for cumulative percentages (Lorenz curve) in order, from the highest to the lowest impact.

When discussing the ABC method, it can be concluded that a small number of causes are responsible for the majority of the issues. Eliminating these 20\% significantly improves the final process. The precise identification of the phenomena allows one to effectively avoid non-significant reasons, because the Pareto principle is based on an analysis of the uneven distribution of decisive factors. The Pareto analysis (which results in the creation of a Pareto-Lorenz diagram) allows for the organization and analysis of the previously collected data. It is used when the goal is to counteract the following:

- negative phenomena with the highest frequency of occurrence,

- phenomena incurring the largest costs.

The Pareto-Lorenz diagram is a tool enabling the hierarchization of the factors affecting the studied phenomenon. It is a visual representation, showing both the relative and absolute distribution of the types of errors and problems as well as their causes. It allows for the presentation of data in a column chart with emphasis on the elements that contribute the most to the analyzed problem (Fig. 7).

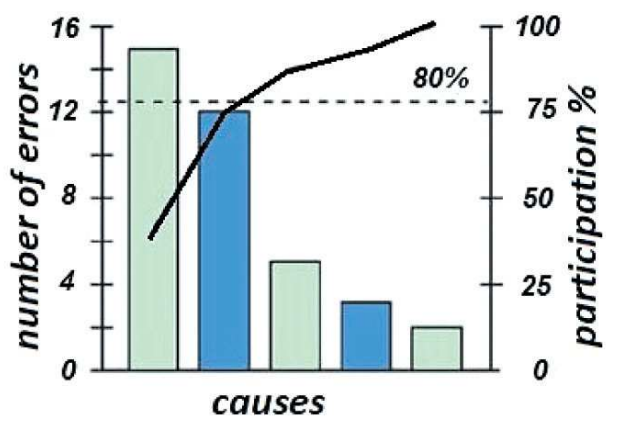

Fig. 7. Pareto-Lorenz diagram

\section{PROBLEM ANALYSIS}

In the mining industry, the Pareto-Lorenz diagram is used to monitor and control the mining equipment (mining machine, armored face conveyor, belt conveyor, powered roof support) that constitutes an important element of the mining process [2]. In the case of these machines/equipment, it is important to assess the failure rate and reliability as well as to indicate which of the detected reasons causing failure frequency should be eliminated first.

The construction of the Pareto-Lorenz diagram for the control and monitoring of mining machinery/ equipment is divided into the following stages:

- collecting information - that is, completing data on the failure rate of mining machines/equipment in the individual stages of the mining process;

- sorting the collected data - assigning particular failures to specific mining machines/equipment such as the mining machine, armored face conveyor, belt conveyor, or powered roof support;

- calculation of cumulative percentages - determination of cumulative percentages for particular highlighted failures;

- drawing a Pareto-Lorenz diagram;

- interpretation of the Pareto-Lorenz diagram.

\section{LONGWALL FAILURE RATE}

Because the mining process line is the fundamental element affecting the output volume in the process of extracting hard coal (useful minerals) and, thus, the costs associated with this process, the failure rate of this fundamental element was analyzed (plow and shearer) $[1,2,6,9]$. The failure rates of two longwalls in hard coal mines were analyzed over the entire period of their operation (from their commissioning to the end of their operation). A traditional quality management tool - the Pareto-Lorenz diagram - was used to analyze the failure rate of the longwall plow complex.

The Pareto-Lorenz diagram was constructed according to the following stages:

- data was collected related to the type of failure of the following mining equipment (machines): the mining machine (plow, shearer), conveyors (AFC, belt), and powered roof support;

- individual failures were assigned to specific mining machines (equipment);

- cumulative percentages were calculated (determination of cumulative percentages for particular highlighted failures).

\section{LONGWALL PLOW SYSTEM}

All breaks in the work on the longwall that occurred over the entire mining period were registered 
by the relevant departments of the mine [10-12]. The piece of equipment (machine) in which the break occurred was assumed as the point of failure. The failure points were as follows:

- conveyors (AFC, beam stage loader, belt),

- plow,

- powered roof support.

Note: in the case of conveyor belts, only failures in the branch transport have been taken into account, disregarding the main haulage.

Table 1 presents the data on the causes of the failures, cumulative percentage number of the individual machines/equipment, breakdown times that occurred for individual elements of the mining complex, percentage number of failures, and cumulative percentage number of failures [5]. Meanwhile, Figure 8 presents a Pareto-Lorenz diagram showing the failure rate of a longwall plow system in the analyzed mine.

Table 1

Failure rate of longwall plow system

\begin{tabular}{|l|c|c|c|c|}
\hline $\begin{array}{c}\text { Failure } \\
\text { cause }\end{array}$ & $\begin{array}{c}\text { Cumul- } \\
\text { ative } \\
\text { percent } \\
\boldsymbol{S P I E} \\
{[\%]}\end{array}$ & $\begin{array}{c}\text { Break- } \\
\text { down } \\
\text { time } \\
\text { min. } \boldsymbol{I A}\end{array}$ & $\begin{array}{c}\text { Percent } \\
\text { number } \\
\text { of failures } \\
\boldsymbol{P I A} \\
{[\%]}\end{array}$ & $\begin{array}{c}\text { Cumulative } \\
\text { number } \\
\text { of failures } \\
\boldsymbol{S P I A} \\
{[\%]}\end{array}$ \\
\hline Conveyors & 33.33 & 13,204 & 57 & 57 \\
\hline Coal plow & 66.66 & 8215 & 35 & 92 \\
\hline $\begin{array}{l}\text { Powered } \\
\text { support }\end{array}$ & 100 & 1822 & 8 & 100 \\
\hline
\end{tabular}

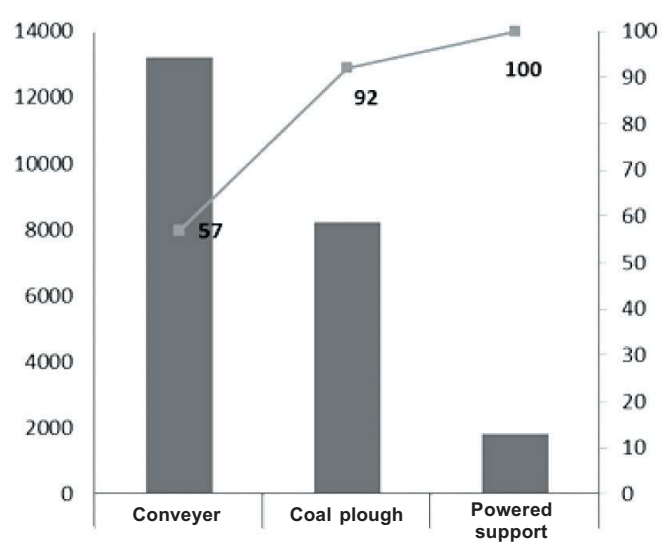

Fig. 8. Pareto-Lorenz diagram for plow longwall analyzed

\section{LONGWALL SHEARER SYSTEM}

The analysis of the longwall shearer system was carried out using the example of one wall in a mine belonging to PGG S.A. in which a two-armed mining machine was installed.
The working time of the analyzed wall from the start of work to the end of its operation was 92 days. All breaks in the work on the wall that occurred over the entire mining period were registered by the mine's dispatcher. The machine/equipment that caused the break was assumed as the point of failure. The points of failure were as follows:

- shearer,

- conveyors (AFC, beam stage loader, belt),

- crusher,

- roof support,

- other.

The sum of all breaks in the operation of the longwall complex is presented in Table 2 and the ParetoLorenz diagram (Fig. 9). Table 2 illustrates the number and time of the breaks in the operation of individual elements in the longwall shearer complex. In terms of the number of breaks, it is clearly visible that the conveyors had the largest failure rate, followed closely by the shearer (Fig. 9). On the other hand, considering the total stoppage time, the sum of the stoppages in the longwall system was affected the most by breaks in the operation of the shearer, followed by the conveyors [10-12].

Table 2

Total stoppage in operation of longwall system

\begin{tabular}{|c|l|c|c|c|c|}
\hline No. & $\begin{array}{c}\text { Breaks } \\
\text { in operation } \\
\text { of element } \\
\text { of longwall } \\
\text { system }\end{array}$ & $\begin{array}{c}\text { Num- } \\
\text { ber } \\
\text { of } \\
\text { breaks }\end{array}$ & $\begin{array}{c}\text { Total } \\
\text { stoppage } \\
\text { time } \\
\text { (min) }\end{array}$ & $\begin{array}{c}\text { Stop- } \\
\text { page } \\
\text { time } \\
\text { for all } \\
\text { breaks } \\
{[\%]}\end{array}$ & $\begin{array}{c}\text { Cumul- } \\
\text { ative } \\
\text { stoppage } \\
\text { time } \\
{[\%]}\end{array}$ \\
\hline 1 & Cutter-loader & 67 & 6065 & 47 & 47 \\
\hline 2 & Conveyor & 70 & 4920 & 39 & 86 \\
\hline 3 & Mining & 14 & 725 & 5 & 91 \\
\hline 4 & Powered support & 19 & 625 & 5 & 96 \\
\hline 5 & Another & 13 & 500 & 4 & 100 \\
\hline \multicolumn{2}{|c|}{ Total: } & & $\mathbf{1 8 3}$ & $\mathbf{1 2 . 8 3 5}$ & $\mathbf{1 0 0}$ \\
\hline
\end{tabular}

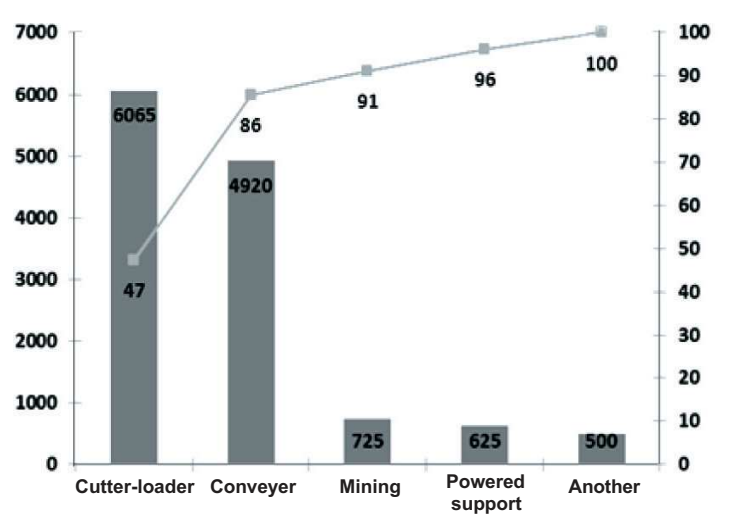

Fig. 9. Pareto-Lorenz diagram for longwall shearer system 
Analyzing the Pareto-Lorenz diagram, it can be concluded that the element of the longwall shearer system that caused the most failures was the mining machine (shearer $-47 \%$ ), followed by the conveyor $(39 \%)$.

\section{CONCLUSIONS}

The Pareto-Lorenz diagram allows for an analysis of the causes of failures and the effects of breaks in the operation of machines/equipment with the greatest impact on stoppages in the mining process in mines.

Analysis of these causes should show whether the failures were caused by the following:

- human factor (errors in operation, maintenance, servicing);

- the devices themselves (design, manufacturing defects);

- others that have not been created as a result of the aforementioned factors; e.g., particularly difficult working conditions.

Upon carrying out the aforementioned analysis, it is necessary to indicate the actions to be taken by those persons operating these machines and equipment to minimize the number of breaks in work that have a significant impact on the economic results of the mine.

In each of the mining systems analyzed (plow, shearer), it can be seen that two elements of the mining complex should be subjected to special analysis. The analysis should indicate the main causes of the failure and which methods and measures should be taken to significantly reduce the failure rate of these elements of the mining system.

In the case of a longwall plow system, the largest failure rate was demonstrated by the conveyors, followed by the plow. On the other hand, the element that caused the longest downtimes in the longwall shearer system was the shearer, followed by the conveyors.

An analysis of the Pareto-Lorenz diagram for a longwall plow system indicates that the largest number of failures $(92 \%)$ are caused by two elements of the mining system; namely, the conveyors (AFC, belt) and plow.

Taking into account the percentage share of these two elements of a mining system, it can be concluded on the basis of the Pareto-Lorenz diagram that a total of $66.7 \%$ of the machines/equipment causes as much as $92 \%$ of all failures.
Analyzing a longwall shearer system, the shearer is the element that causes the most failures (47\%); this is why a thorough analysis of the failure rate of the shearer should be carried out in the next stage.

Persons monitoring and controlling the operation of machines/equipment should take special care of the technical condition of these machines/equipment and try to prevent the occurrence of failures. Failures of individual mining machines (and longwall shearers in particular) cause large losses for a mine, which is why it seems reasonable to propose actions that would help reduce the number of potential breakdowns of these machines. This is why employees connected with operating the machines (equipment) should be frequently trained in the field of operation and exploitation in order to avoid frequent stoppages; in particular, on issues such as the following:

- the purpose, design, and principle of operation as well as the application of a control and diagnostic system;

- principles of operation and installation of system sensors;

- structure, design, and principle of operation of the components and subassemblies;

- methods of installation, commissioning, and operation;

- diagnostics and analysis of the causes of failures and their elimination;

- operating guidelines;

- health and safety requirements.

In this group of failures, the employee is not a direct cause, but he can effectively prevent the emergence of some of these failures. You can reduce removal time by frequent staff training on breakdown recovery. Training connected with the proper maintenance of equipment (machines) should also be carried out, which should contribute to the prolongation of the failure-free operation of the machines.

The failure rate of the mining system (plow and shearer) directly translates into the efficiency and concentration of extraction, which ultimately reflects in the financial result of the mine.

\section{Acknowledgements}

This article is the result of research conducted at the Institute of Production Engineering, Faculty of Organization and Management, Silesian University of Technology, within the statutory work entitled "Development of intelligent production methods as 
well as work and life environments in the context of production engineering challenges" (symbol 13/030/ BK_18/0039).

\section{References}

[1] Biały W.: Górnictwo węgla kamiennego - wybrane problemy funkcjonowania. Monografia, Wydawnictwo PKJS, Gliwice 2011.

[2] Biały W.: Innovative solutions applied in tools for determining coal mechanical properties, "Management Systems in Production Engineering" 2015, 4: 202-209.

[3] Łucki Z.: Zarządzanie w górnictwie naftowym i gazownictwie, TAiWPN Universitas, Kraków 2005.

[4] Skotnicka-Zasadzień B., Biały W.: An analysis of possibilities to use a Pareto chart for evaluating mining machines' failure frequency, "Eksploatacja i Niezawodność" 2011, 3: 51-55.

[5] Peter F.: Rethinking Pareto analysis maintenance applications of logarithmic scatterplots, "Journal of Quality and Maintenance Engineering" 2001, 4: 252-263.

[6] Franik T: Monitorowanie podstawowych parametrów procesów produkcyjnych $w$ kopalni węgla kamiennego, in: Komputerowo zintegrowane zarzadzanie, red. R. Knosala, Oficyna Wydawnicza Polskiego Towarzystwa Zarządzania Produkcją, Opole 2009.
[7] Midor K.: An analysis of the causes of product defects using quality management tools, "Management Systems in Production Engineering" 2014, 4: 162-167.

[8] Ziółkowski J., Łada J.: Analiza ABC i XYZ w gospodarowaniu zapasami, Wydawnictwo Społecznej Akademii Nauk, Łódź 2014.

[9] Zasadzień M.: Using the Pareto diagram and FMEA (Failure Mode and Effects Analysis) to identify key defects in a product, "Management Systems in Production Engineering" 2016, 4: 153-156.

[10] Report books from the Department of Chiefs Mechanics.

[11] Daily reports of the main dispatcher of the mine.

[12] Wall Technical Project.

WITOLD BIAEY, Assoc. Prof. PATRYCJA HĄBEK, Assoc. Prof. Institute of Production Engineering Faculty of Organization and Management Silesian University of Technology ul. Roosevelta 26, 41-800 Zabrze, Poland \{wbialy, phabek\}@polsl.pl 
WITOLD BIAŁY

PATRYCJA HĄBEK

\title{
Narzędzia inżynierii jakości w analizie awaryjności ścianowych kompleksów wydobywczych
}

\begin{abstract}
Przerwy spowodowane awaryjnościa maszyn wplywaja na efektywność procesu wydobywczego. Głównym zadaniem stużb utrzymania ruchu w kopalniach węgla kamiennego jest zapewnienie ciagtości pracy eksploatowanych maszyn (urządzeń). Wymiernym efektem tych dziatań powinno być ograniczenie kosztów utrzymania ruchu maszyn (urzadzeń), a tym samym obniżenie kosztów produkcji wydobycia węgla, czyli działania kopalni. W niniejszym artykule przeanalizowano dwa kompleksy ścianowe: kombajnowy oraz strugowy. Do analizy wykorzystano jedno z narzędzi inżynierii jakości - diagram Pareto-Lorenza. Narzędzie to pozwala pogrupować przyczyny awarii oraz wskazać, które z nich sa najistotniejsze i które powinny być w pierwszej kolejności usuwane. Przeprowadzona analiza wskazała, jak istotny jest właściwy dobór maszyn (urządzeń) do istniejących warunków geologiczno-górniczych. Niewtaściwy dobór skutkuje wzrostem energochłonności procesu wydobywczego, przedwczesnym zużyciem czy zwiększonymi przerwami w pracy, które sa spowodowane awariami.
\end{abstract}

Słowa kluczowe: kompleksy ścianowe, awarie, wydobycie, diagram Pareto-Lorenza

\section{WSTĘP}

W górnictwie węglowym (tak światowym, jak i polskim), eksploatacja pokładów węglowych odbywa się systemami ścianowymi za pomocą maszyn urabiających pracujących na zasadzie skrawania. Dlatego też jednym z istotnych obszarów działalności kopalń jest eksploatacja maszyn i urządzeń niezbędnych do prawidłowego funkcjonowania. Działanie to powinno polegać między innymi na kontroli racjonalnego oraz efektywnego użytkowania i obsługiwania maszyn i urządzeń w procesie ich eksploatacji [1-4]. Aktualnie w górnictwie polskim (również światowym), zastosowanie znalazły dwa systemy: kombajnowy (rys. 1) oraz strugowy (rys. 2). Proces urabiania w obu systemach jest identyczny, natomiast różnica polega na zainstalowanej w tym procesie maszynie urabiającej - kombajn lub strug. Pozostałe elementy systemu pozostają bez zmian.

Efektywność prawidłowo zaprojektowanego systemu mechanizacyjnego oraz jego niezawodność bezpośrednio rzutują na wynik ekonomiczny przedsiębior- stwa. Rozwój technologiczny w górnictwie, zwiększająca się kompleksowość, wydajność oraz moc stosowanych maszyn i urządzeń górniczych stawia coraz większe wymagania kultury ich użytkowania. Urządzenia te muszą spełniać warunki energooszczędności, niezawodności, wysokiej trwałości oraz bezpieczeństwa pracy.

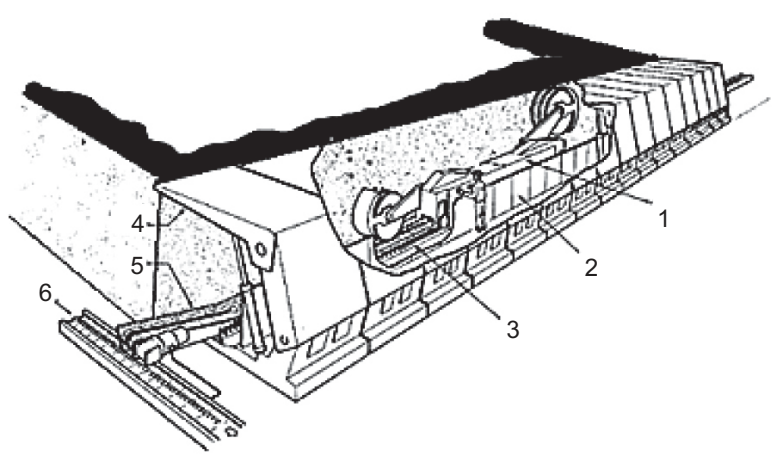

Rys. 1. Ścianowy kompleks kombajnowy:

1 - kombajn, 2 - zastawka, 3 - drabinka, 4-ścianowa obudowa zmechanizowana, 5 - przenośnik zgrzebtowy ścianowy, 6 - przenośnik zgrzebłowy podścianowy [1] 


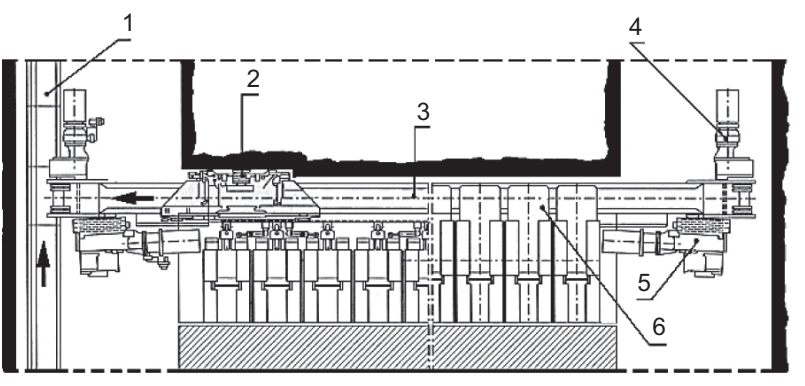

Rys. 2. Ścianowy kompleks strugowy: 1 - przenośnik zgrzebłowy podścianowy, 2 - strug, 3 - przenośnik zgrzebtowy ścianowy, 4 - napęd przenośnika, 5 - napęd struga, 6 - ścianowa obudowa zmechanizowana [1]

Maszyny i urządzenia górnicze są złożonymi obiektami technicznymi, które powinny charakteryzować się odpowiednio wysoką trwałością i niezawodnością działania w stosunkowo długim czasie eksploatacji. $\mathrm{Na}$ określone kształtowanie się tych cech znaczny wpływ ma nie tylko sam proces ich projektowania, konstruowania i montażu, ale przede wszystkim (podczas szeroko rozumianego procesu użytkowania), prawidłowa dbałość o stan techniczny. Gwarancją uzyskania niezawodności i wysokiej trwałości urządzeń w czasie eksploatacji, jest stosowanie diagnostyki technicznej, która pozwala poprawnie określić stan techniczny maszyn. Stąd głównym zadaniem służb utrzymania ruchu w kopalni jest zapewnienie ciągłości pracy eksploatowanych (w danej chwili) urządzeń i maszyn. Konsekwencją tych działań jest ograniczenie kosztów utrzymania ruchu urządzeń i maszyn, co wiąże się z obniżeniem kosztów produkcji, czyli działania zakładu górniczego. W przypadku wystąpienia zakłóceń w tym procesie, generowane są ogromne straty.

W niniejszym artykule do oceny awaryjności urządzeń i maszyn górniczych wykorzystano jedno z tradycyjnych narzędzi zarządzania jakością - diagram Pareto-Lorenza [4, 5]. Za pomocą tego graficznego obrazu można przedstawić zarówno względny, jak i bezwzględny rozkład rodzajów błędów, problemów i przyczyn ich powstawania [6].

$\mathrm{W}$ procesie wydobywania kopaliny głównym elementem jest ciąg urabiania, w którym można wyszczególnić trzy następujące po sobie etapy [1, 4]:

- proces urabiania,

- transport poziomy,

- transport pionowy.

Analizując ciąg urabiania, można stwierdzić, że mamy do czynienia z systemem szeregowym - awaria jednego z ogniw powoduje „wyłączenie” pozostałych elementów tego ciągu (rys. 3).

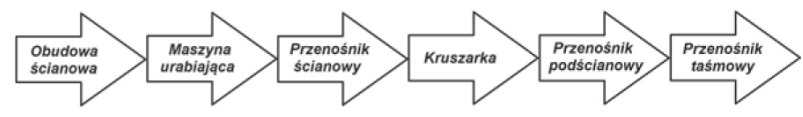

Rys. 3. Elementy składowe ciagu urabiania

\section{UTRZYMANIE RUCHU CIAZGU URABIANIA}

Utrzymanie ruchu maszyn czy urządzeń górniczych realizowane jest przez służby związane z kopalnią, jak również przez firmy zewnętrzne. W przypadku firm zewnętrznych, najczęściej są to producenci danej maszyny czy urządzenia.

Każda maszyna czy urządzenie zainstalowane w kopalni, podlega działaniom konserwacyjno-naprawczym, które można rozłożyć na czynniki lokalizujące je w strukturze napraw i odpowiednio zlokalizować w strukturze napraw (rys. 4):

- remonty/konserwacja elementów hydraulicznych (pneumatycznych),

- remonty/konserwacja elementów mechanicznych,

- remonty/konserwacja elementów elektrycznych.

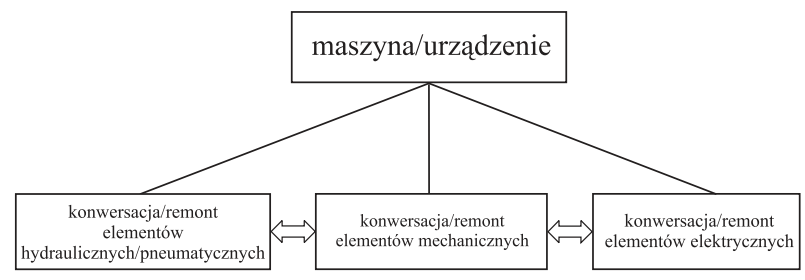

Rys. 4. Schemat blokowy struktury napraw

Model, za pomocą którego aktualnie rejestruje się dane o awariach maszyn/urządzeń górniczych w jednej z kopalń PGG, przedstawiono na rysunku 5.

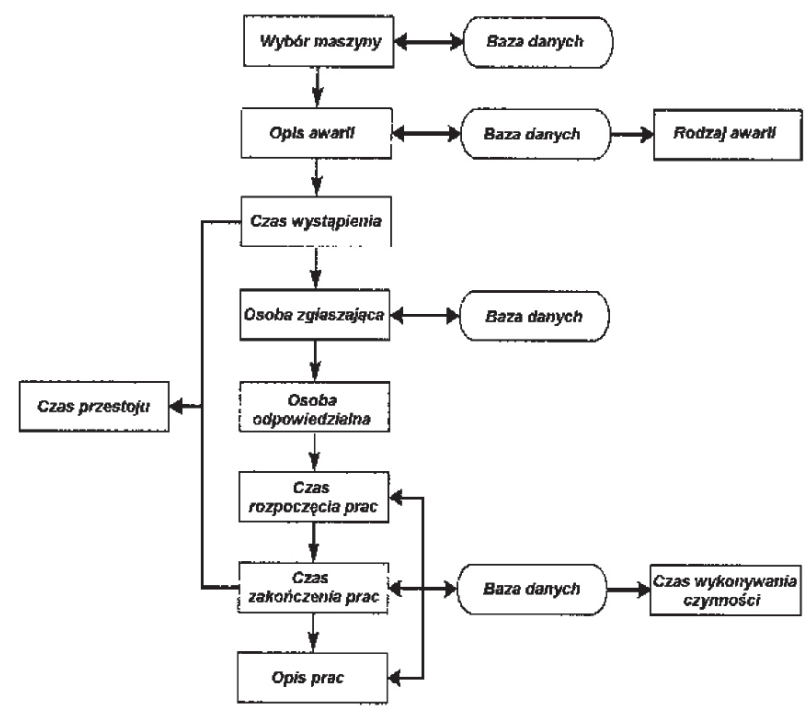

Rys. 5. Schemat rejestracji awarii maszyn/urzadzeń w kopalni $P G G$ 
$\mathrm{Na}$ podstawie obserwacji można stwierdzić, że obecnie w polskich kopalniach węgla kamiennego nie został opracowany jednolity system zarządzania utrzymaniem ruchu maszyn górniczych tak w procesie eksploatacji, jak i remontów. System ten powinien uwzględniać [1]:

- obserwację, rejestrację oraz analizę poszczególnych czynności;

- harmonogramowanie czynności;

- sposób gromadzenia informacji o maszynach i urządzeniach;

- tryb uzgadniania zakresu prac serwisowych pomiędzy użytkownikiem a wytwórcą;

- kształtowanie właściwych kompetencji pracowników realizujących czynności z zakresu utrzymania ruchu;

- gromadzenie i przetwarzanie informacji prowadzenia prac z zakresu utrzymania ruchu.

Do monitorowania oraz kontroli maszyn/urządzeń ścianowego kompleksu wydobywczego można wykorzystać inżynierię jakości. Wykorzystanie elementów inżynierii jakości w większości przedsiębiorstw produkcyjnych ma na celu przedstawienie wystąpienia potencjalnych wad w wyrobie lub cyklu produkcyjnym. Wykorzystanie narzędzi zarządzania jakością pozwala na monitorowanie cyklu produkcyjnego, począwszy od fazy projektowej, przez produkcję, kończąc na etapie końcowym, czyli dostarczeniu gotowego wyrobu klientowi. Narzędzia inżynierii jakości do oceny skutków awarii przyczynią się w znaczący sposób do zmniejszenia strat, które są związane z nieplanowanymi przestojami (awariami). Stąd też uzasadnione wydaje się wykorzystanie narzędzi inżynierii jakości w procesie produkcyjnym (wydobywczym), co pozwoli na skuteczne zmniejszenie strat powstałych w wyniku awarii. Dlatego proponuje się włączenie elementów inżynierii jakości do wyznaczania przyczyn awarii w procesie wydobywczym (rys. 6).

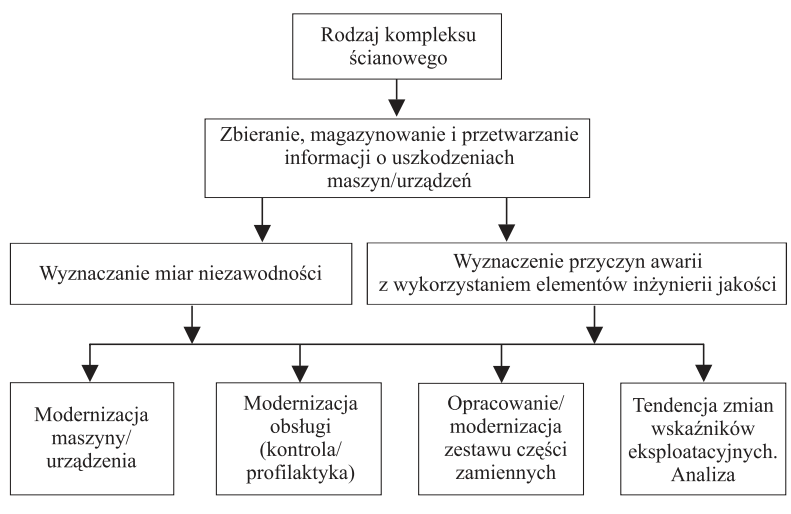

Rys. 6. Inżynieria jakości w określaniu przyczyn awarii

Praktyczne zastosowanie wybranych elementów inżynierii jakości w procesie produkcyjnym (w tym przypadku wydobywczym) pozwoli na zmniejszenie strat związanych z przestojami wynikającymi z awarii maszyn/urządzeń.

\section{INŻYNIERIA JAKOŚCI A AWARYJNOŚĆ MASZYN/URZALZEŃ}

Przez inżynierię jakości rozumie się kształtowanie, modelowanie oraz implementację systemów jakości według określonych standardów i norm, zarządzanie jakością, metody certyfikacji systemów jakości, metody akredytacji i audytu, sterowanie procesami, metrologię, prawne aspekty jakości oraz metody kompleksowego zarządzania jakością TQM.

Do dobrego skutecznego zarządzania jakością kadrze zarządzającej potrzebne są informacje. Muszą być one rzetelne, aktualne i przede wszystkim prawdziwe. Zarządzanie przez jakość ma na celu udoskonalanie produktów i/lub usług - stwarzanie i ochrona ich jakości, tak aby zadowolić klienta. Jest to kompleksowa działalność, a w jej realizacji pomagają różnego rodzaju narzędzia i metody.

Narzędzia jakości są wykorzystywane do zbierania, przetwarzania informacji, do nadzorowania procesu zarządzania przez jakość, do wykrywania błędów, wad i nieprawidłowości w przebiegach procesów, produktach lub usługach. Pozwalają na wizualizację danych, monitorowanie i diagnozowanie procesów. Dzięki nim możemy sprawdzić efektywność podjętych działań. Są one instrumentami, które pozwalają na monitorowanie działań (procesów) w całym cyklu życia wyrobu.

Narzędzia zarządzania jakością dzielimy na tradycyjne, nowe oraz dodatkowe. Tradycyjne narzędzia są nazywane wielką siódemką (ang. magnificient seven). Są one najczęściej wykorzystywane i mają znaczenie podstawowe. Narzędzia te mogą być stosowane samodzielnie, ale często używa się ich jako składników metod zarządzania jakością. Jednym z tradycyjnych narzędzi zarządzania jakością jest diagram Pareto-Lorenza [7-9].

Diagram Pareto-Lorenza, nazywany również metodą $\mathrm{ABC}$, prawem nierównomierności rozkładu lub prawem 20-80, używany jest w celu identyfikacji i oceny istotności analizowanych zagadnień. Identyfikowane są te problemy, które mimo stanowienia mniejszości względem liczebności pozostałych (20\%) wywierają dominujący wpływ na rozpatrywane zagadnienie (80\%).

Procedura przeprowadzania analizy według metody ABC sprowadza się do:

- identyfikacji rodzajów rozpatrywanych zagadnień (np. rodzajów wad);

- określenia przedziału czasowego (dzień, zmiana, rok itp.) w celu późniejszego porównywania efektów wprowadzonych zmian; 
- ustalenia częstości występowania poszczególnych kategorii (np. przyczyn, wad);

- uszeregowania kategorii według malejącej częstości występowania, obliczenia częstości procentowych oraz skumulowanych;

- ustalenia skal na osi pionowej (najczęściej przyjmuje się bezwzględną częstość występowania oraz procent skumulowany) i poziomej (kategorie);

- naniesienia na wykres słupków odpowiadających częstości dla poszczególnych kategorii (wykres Pareto) i krzywej dla procentów skumulowanych (krzywa Lorenza), w kolejności od największego do najmniejszego nasilenia oddziaływania.

Omawiając metodę $\mathrm{ABC}$, można stwierdzić, że niewielka liczba przyczyn odpowiada za większość występujących zjawisk. Zlikwidowanie tych $20 \%$ znacząco poprawia końcowy proces. Precyzyjna identyfikacja zjawisk pozwala w skuteczny sposób uniknąć przyczyn mało istotnych, ponieważ zasada Pareto opiera się na analizie nierównego rozkładu czynników decyzyjnych. Analiza Pareto (której wynikiem jest diagram Pareto-Lorenza) pozwala na uporządkowanie i przeanalizowanie wcześniej zebranych danych. Stosuje się ją wtedy, gdy naszym celem jest przeciwdziałanie:

- zjawiskom negatywnym o największej częstotliwości występowania,

- zjawiskom przysparzającym największych kosztów.

Diagram Pareto-Lorenza jest narzędziem umożliwiającym hierarchizację czynników wpływających na badane zjawisko. Jest on graficznym obrazem, pokazującym zarówno względny, jak i bezwzględny rozkład rodzajów błędów, problemów oraz ich przyczyn. Pozwala przedstawić dane na wykresie kolumnowym z uwydatnieniem elementów dających największy wkład do analizowanego problemu (rys. 7).

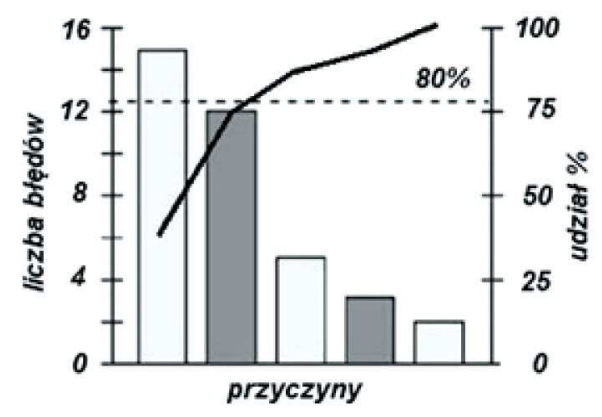

Rys. 7. Diagram Pareto-Lorenza

\section{ANALIZA PROBLEMU}

W przemyśle górniczym (wydobywczym) diagram Pareto-Lorenza znajduje zastosowanie do monitoro- wania i kontroli urządzeń górniczych (maszyna urabiająca, przenośnik zgrzebłowy, przenośnik taśmowy, obudowa zmechanizowana), które stanowią ważny element procesu wydobywczego w kopalni [2]. W przypadku tych maszyn/urządzeń istotna jest ocena awaryjności i niezawodności, a także wskazanie, które z wykrytych przyczyn powodujących awaryjność powinny być jako pierwsze wyeliminowane.

Konstruowanie diagramu Pareto-Lorenza do kontroli i monitorowania maszyn/urządzeń górniczych dzieli się na następujące etapy:

- zbieranie informacji - czyli skompletowanie danych o awaryjności maszyn/urządzeń górniczych w poszczególnych etapach procesu wydobywczego;

- uszeregowanie zebranych danych - przyporządkowanie poszczególnych awarii do konkretnych maszyn/urządzeń górniczych, takich jak: maszyna urabiająca, przenośnik zgrzebłowy, przenośnik taśmowy, obudowa zmechanizowana;

- obliczenie skumulowanych wartości procentowych - ustalenie skumulowanych wartości procentowych dla poszczególnych wyróżnionych awarii;

- sporządzenie diagramu Pareto-Lorenza;

- interpretacja sporządzonego diagramu ParetoLorenza.

\section{AWARYJNOŚĆ ŚCIAN WYDOBYWCZYCH}

Jako że w procesie wydobywania węgla kamiennego (kopalin użytecznych) ciąg urabiania jest podstawowym elementem wpływającym na wielkość wydobycia, a tym samym na związane z tym procesem koszty przeanalizowano awaryjność tego podstawowego elementu (strugowego oraz kombajnowego) $[1,2,6,9]$. Przeanalizowano awaryjność dwóch ścian wydobywczych w kopalniach węgla kamiennego w całym okresie ich eksploatacji (od momentu uruchomienia do zakończenia eksploatacji). Do analizy awaryjności ścianowego kompleksu strugowego zostało wykorzystane tradycyjne narzędzie zarządzania jakością - diagram Pareto-Lorenza.

Diagram Pareto-Lorenza skonstruowano, wykonując następujące czynności:

- zebrano dane związane z rodzajem awarii następujących urządzeń (maszyn) górniczych: maszyny urabiającej (struga, kombajnu), przenośników (zgrzebłowych, taśmowych), obudowy zmechanizowanej;

- przyporządkowano poszczególne awarie do konkretnych maszyn (urządzeń) górniczych;

- obliczono skumulowane wartości procentowe (ustalenie skumulowanych wartości procentowych dla poszczególnych wyróżnionych awarii). 


\section{6. ŚCIANOWY KOMPLEKS STRUGOWY}

Wszystkie przerwy w pracy ściany, powstałe w ciągu całego okresu wydobywczego zostały zarejestrowane przez odpowiednie służby kopalni [10-12]. Jako miejsce wystąpienia awarii przyjęto urządzenie (maszynę), w którym wystąpiła przerwa w pracy. Miejsca awarii to:

- przenośniki (ścianowy, podścianowy, taśmowy),

- strug,

- obudowa.

Uwaga: w przypadku przenośników taśmowych uwzględniano tylko awarie w transporcie oddziałowym z pominięciem odstawy głównej.

W tabeli 1 przedstawiono dane dotyczące przyczyn awarii, skumulowaną procentową liczbę poszczególnych maszyn/urządzeń, czasy awarii, jakie wystąiły dla poszczególnych elementów kompleksu wydobywczego, procentową liczbę awarii oraz skumulowaną procentową liczbę awarii [5]. Natomiast na rysunku 8 przedstawiono diagram Pareto-Lorenza ukazujący awaryjność ścianowego kompleksu strugowego w analizowanej kopalni.

\section{Tabela 1}

Awaryjność ścianowego kompleksu strugowego

\begin{tabular}{|l|c|c|c|c|}
\hline $\begin{array}{c}\text { Przyczyna } \\
\text { awarii }\end{array}$ & $\begin{array}{c}\text { Skumulowa- } \\
\text { na liczba } \\
\text { SPIE [\%] }\end{array}$ & $\begin{array}{c}\text { Czas } \\
\text { awarii } \\
\text { min } \boldsymbol{I A}\end{array}$ & $\begin{array}{c}\text { Liczba } \\
\text { awarii } \\
\text { PIA [\%] }\end{array}$ & $\begin{array}{c}\text { Skumulowana } \\
\text { liczba awarii } \\
\text { SPIA [\%] }\end{array}$ \\
\hline Przenośniki & 33,33 & 13204 & 57 & 57 \\
\hline $\begin{array}{l}\text { Maszyna } \\
\text { urabiająca }\end{array}$ & 66,66 & 8215 & 35 & 92 \\
\hline Obudowa & 100 & 1822 & 8 & 100 \\
\hline
\end{tabular}

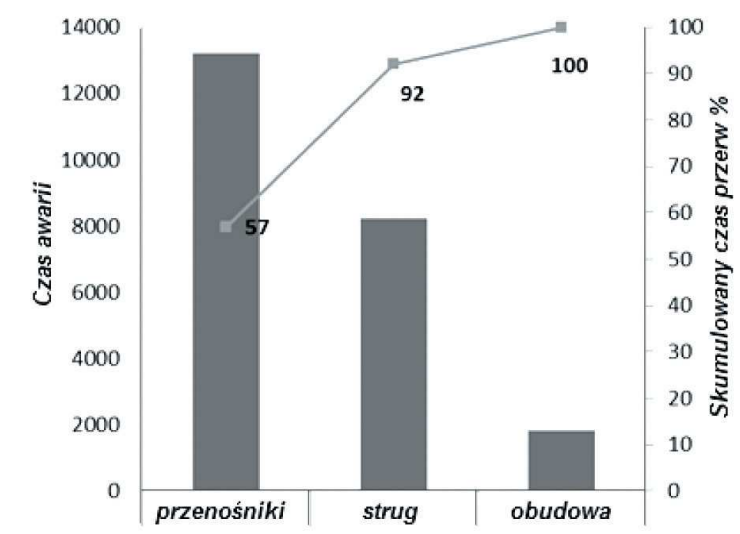

Rys. 8. Diagram Pareto-Lorenza

dla analizowanej ściany strugowej

\section{7. ŚCIANOWY KOMPLEKS KOMBAJNOWY}

Analiza ścianowego kompleksu kombajnowego przeprowadzona została na przykładzie jednej ściany, w kopalni należącej do PGG S.A., w której zainstalowany był dwuramionowy kombajn wydobywczy.

Czas pracy analizowanej ściany od momentu jej uruchomienia do zakończenia eksploatacji, wyniósł 92 dni. Wszystkie przerwy w pracy ściany, powstałe w ciągu całego okresu wydobywczego zostały zarejestrowane przez dyspozytora kopalni. Jako miejsce wystąpienia awarii przyjęto maszynę/urządzenie, w którym wystąiła przerwa w pracy. Miejsca awarii to:

- kombajn,

- przenośniki (ścianowy, podścianowy, taśmowy),

- kruszarka,

- obudowa,

- inne.

Sumę wszystkich przerw w pracy kompleksu ścianowego przedstawia tabela 2 oraz diagram ParetoLorenza (rys. 9). Tabela 2 ilustruje liczbę oraz czasy przerw w pracy poszczególnych elementów ścianowego kompleksu kombajnowego. Pod względem liczby przerw wyraźnie widać, że największą awaryjność miały przenośniki, a tuż za nimi plasuje się kombajn (rys. 9). Natomiast na łączną sumę czasu przerw kompleksu ścianowego największy wpływ miały przerwy w pracy kombajnu, a następnie przenośników [10-12].

Tabela 2

\section{Suma przerw w pracy kompleksu ścianowego}

\begin{tabular}{|l|c|c|c|c|}
\hline $\begin{array}{c}\text { Przerwy w pracy } \\
\text { elementu } \\
\text { ścianowego } \\
\text { kompleksu } \\
\text { kombajnowego }\end{array}$ & Liczba & $\begin{array}{c}\text { Lączny } \\
\text { czas } \\
\text { przerw } \\
\text { [min.] }\end{array}$ & $\begin{array}{c}\text { Czas } \\
\text { trwania } \\
\text { wszystkich } \\
\text { przerw } \\
{[\%]}\end{array}$ & $\begin{array}{c}\text { Skumu- } \\
\text { lowany } \\
\text { czas } \\
\text { przerw } \\
{[\%]}\end{array}$ \\
\hline Kombajn & 67 & 6065 & 47 & 47 \\
\hline Przenośnik & 70 & 4920 & 39 & 86 \\
\hline Górnicza & 14 & 725 & 5 & 91 \\
\hline $\begin{array}{l}\text { Obudowa } \\
\text { zmechanizowana }\end{array}$ & 19 & 625 & 5 & 96 \\
\hline Inna & 13 & 500 & 4 & 100 \\
\hline \multicolumn{1}{|c|}{ Suma } & & $\mathbf{1 8 3}$ & $\mathbf{1 2 ~ 8 3 5}$ & $\mathbf{1 0 0}$ \\
\hline
\end{tabular}

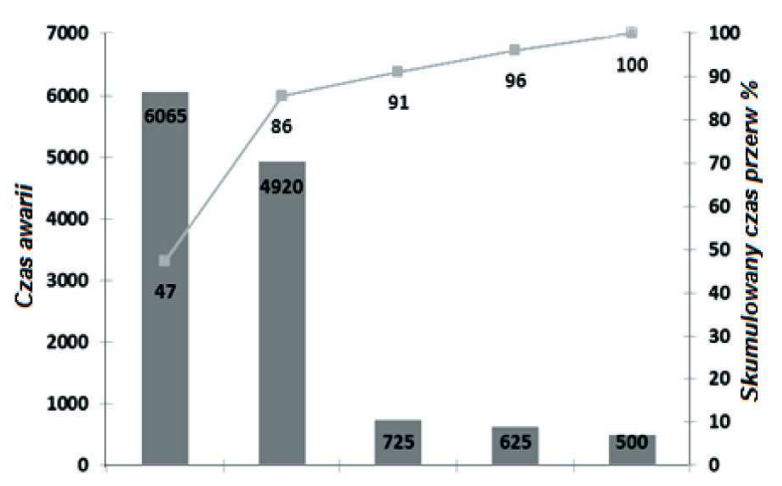

Rys. 9. Diagram Pareto-Lorenza dla ścianowego kompleksu kombajnowego 
Z diagramu Pareto-Lorenza (rys. 9) wynika, że przerwy w pracy kombajnu i przenośników powodują największe przestoje $\mathrm{w}$ pracy kompleksu ścianowego ich łączna suma wynosi $86 \%$. Suma przerw zaliczonych do grupy: górnicze, obudowa zmechanizowana i „inne”, a które nie powstały z winy człowieka i nie są związane ze zużyciem się poszczególnych elementów kompleksu ścianowego stanowi tylko $14 \%$.

Analizując wykres Pareto-Lorenza, można stwierdzić, że najbardziej awaryjnym elementem ścianowego kompleksu kombajnowego okazała się maszyna urabiająca (kombajn 47\%), następnie przenośnik $(39 \%)$.

\section{PODSUMOWANIE}

Diagram Pareto-Lorenza pozwala przeanalizować przyczyny awarii oraz skutki dla kopalni, które są wynikiem powstawania przerw $\mathrm{w}$ pracy maszyn/urzadzeń, mających największy wpływ na przestoje ciągu urabiania.

Analiza tych przyczyn powinna wykazać, czy awarie zostały spowodowane przez:

- czynnik ludzki (błędy w eksploatacji, konserwacji, obsłudze);

- spowodowane przez same urządzenia (błędy konstrukcyjne, wykonawcze);

- inne, które nie powstały w wyniku wcześniej wymienionych kryteriów, np. szczególnie trudnych warunków pracy.

Po przeprowadzeniu ww. analizy należy wskazać na działania, jakie powinny podjać osoby obsługujące te urządzenia, aby zminimalizować przerwy w pracy mające istotny wpływ na wyniki ekonomiczne osiagane przez kopalnię.

W każdym $\mathrm{z}$ analizowanych systemów wydobywczych (strugowych, kombajnowych) wynika, że dwa elementy kompleksu wydobywczego powinny być poddane szczególnej analizie. Analiza powinna wskazać główne przyczyny wystąpienia awarii oraz na to, jakie należy podjąć działania zapobiegawcze, aby zdecydowanie zmniejszyć awaryjność tych elementów kompleksu wydobywczego.

W przypadku ścianowego kompleksu strugowego największą awaryjnością wykazały się przenośniki, w następnej kolejności strug. Natomiast w ścianowym systemie kombajnowym elementem, który powodował najdłuższe przerwy w pracy, był kombajn, następnie przenośniki.
Z analizy diagramu Pareto-Lorenza dla ścianowego kompleksu strugowego wynika, że największą liczbę awarii (92\%) powodują dwa elementy kompleksu wydobywczego, a mianowicie: przenośniki (zgrzebłowe, taśmowe) oraz strug.

Biorąc pod uwagę procentowy udział tych dwu elementów kompleksu wydobywczego, na podstawie diagramu Pareto-Lorenza można stwierdzić, że łącznie $66,7 \%$ rodzajów maszyn/urządzeń, powoduje aż $92 \%$ awarii.

Najbardziej awaryjnym elementem w ścianowym systemie kombajnowym jest kombajn (47\%) - dlatego w następnym etapie należałoby przeprowadzić szczegółową analizę awaryjności kombajnu.

Osoby monitorujące i kontrolujące pracę maszyn/ urządzeń powinny w szczególny sposób zadbać o stan techniczny tych maszyn/urządzeń i starać się zapobiegać wystąpieniu awarii. Awarie poszczególnych maszyn górniczych, a zwłaszcza kombajnów ścianowych powodują duże straty dla kopalni, dlatego zasadne wydaje się zaproponowanie działań, które pomogłyby ograniczyć liczbę potencjalnych awarii tych maszyn. Aby więc nie dochodziło do częstych postojów, pracownicy związani z obsługą maszyn (urządzeń), powinni być często szkoleni w zakresie obsługi i eksploatacji, szczególnie w takich zagadnieniach, jak:

- przeznaczenie, budowa oraz zasada działania i zastosowanie systemu sterowania oraz diagnostyki;

- zasady działania i instalowania czujników systemu;

- struktura, budowa i zasada działania części składowych i podzespołów;

- metody instalacji, uruchamiania oraz obsługi;

- diagnostyki i analizy przyczyn awarii i ich usuwania;

- wytyczne eksploatacji;

- wymagania BHP.

Chociaż człowiek nie przyczynia się bezpośrednio do ww. awarii, to może skutecznie zapobiegać powstawaniu niektórych z nich. Można zmniejszyć czas ich usunięcia dzięki częstym szkoleniom personelu dotyczące usuwania skutków awarii. Należy również przeprowadzać szkolenia związane $\mathrm{z}$ właściwą konserwacją urządzeń (maszyn), co przyczyni się do przedłużenia bezawaryjnej pracy urządzeń (maszyn).

Awaryjność kompleksu wydobywczego (zarówno strugowego, jak i kombajnowego) w bezpośredni sposób przekłada się na efektywność, koncentrację wydobycia, co w ostateczności skutkuje wynikiem finansowym kopalni. 


\section{Podziękowania}

Artykuł został sfinansowany ze środków pracy statutowej 13/030/BK_18/0039 realizowanej w Instytucie Inżynierii Produkcji na Wydziale Organizacji i Zarządzania Politechniki Śląskiej.

\section{Literatura}

[1] Biały W.: Górnictwo wegla kamiennego - wybrane problemy funkcjonowania. Monografia, Wydawnictwo PKJS, Gliwice 2011.

[2] Biały W.: Innovative solutions applied in tools for determining coal mechanical proprerties, „Management Systems in Production Engineering" 2015, 4: 202-209.

[3] Łucki Z.: Zarządzanie w górnictwie naftowym i gazownictwie, TAiWPN Universitas, Kraków 2005.

[4] Skotnicka-Zasadzień B., Biały W.: An analysis of possibilities to use a Pareto chart for evaluating mining machines' failure frequency, „Eksploatacja i Niezawodność” 2011, 3: 51-55.

[5] Peter F.: Rethinking Pareto analysis maintenance applications of logarithmic scatterplots, ,Journal of Quality and Maintenance Engineering" 2001, 4: 252-263.

[6] Franik T.: Monitorowanie podstawowych parametrów procesów produkcyjnych w kopalni węgla kamiennego, w: Komputerowo zintegrowane zarządzanie, t. 1, red. R. Knosala, Oficyna Wydawnicza Polskiego Towarzystwa Zarządzania Produkcją, Opole 2009, s. 286-295.
[7] Midor K.: An analysis of the causes of product defects using quality management tools, „Management Systems in Production Engineering" 2014, 4: 162-167.

[8] Ziółkowski J., Łada J.: Analiza ABC i XYZ w gospodarowaniи zapasami, Wydawnictwo Społecznej Akademii Nauk, Łódź 2014.

[9] Zasadzień M.: Using the Pareto diagram and FMEA (Failure Mode and Effects Analysis) to identify key defects in a product, „Management Systems in Production Engineering” 2016, 4: 153-156.

[10] Książki raportowe działu Głównego Mechanika ds. dołu.

[11] Raporty dzienne dyspozytora głównego kopalni.

[12] Projekt Techniczny Ściany.

dr hab. inż. WITOLD BIAŁY, prof. PŚ dr hab. inż. PATRYCJA HABBEK, prof. PŚ

Instytut Inżynierii Produkcji Wydziat Organizacji i Zarządzania Politechnika Śląska ul. Roosevelta 26, 41-800 Zabrze \{wbialy, phabek\}@polsl.pl 